\title{
ЛІНГВІСТИЧНА ЕКСПЕРТИЗА ТЕКСТУ: ЗРАЗОК АКТУАЛЬНОГО АНАЛІЗУ
}

\author{
ХРИСТИНА ПАЗЮРИСТА \\ Національний університет „Львівська політехніка”, Львів - Україна \\ LINGWISTYCZNA EKSPERTYZA TEKSTU: \\ WZÓR AKTUALNEJ ANALIZY \\ KRYSTYNA PAZIURYSTA \\ Narodowy Uniwersytet „Politechnika Lwowska”, Lwów — Ukraina
}

STRESZCZENIE. W artykule przedstawiono typową ekspertyzę lingwistyczną tekstu. Ekspertyza została przeprowadzona przez autorkę artykułu na zlecenie obrońcy w sprawie obrazy honoru, godności i reputacji, dotyczącej zaprzeczenia obecności negatywnej informacji w artykule prasowym oraz odpowiedniej oceny faktów.

\section{LINGUISTIC TEXT EXPERT EXAMINATION: ACTUAL ANALYSIS SAMPLE \\ KHRYSTYNA PAZYURYSTA \\ Lviv National Polytechnic University, Lviv — Ukraine}

ABSTRACT. A typical example of the linguistic text expert examination is represented in the article. The author carried out the examination based on the defense request in the case of honour, dignity and business reputation protection on the subject of refuting negative information presence in the article and corresponding fact evaluation.

$\mathrm{C}$

пецифіка організації висновків лінгвістичних експертиз виявляється в їхній спрямованості не лише до наукової лінгвістичної спільноти, але вони

повинні бути підготовлені так, щоб їх адекватно зрозуміли й не лінгвісти (нефахівці). Вплив на адресата — реалізація задуму адресанта, який очікує адекватної інтерпретації свого замислу від читача (слухача) відповідно до використаних мовних засобів.

Спосіб подання висновків лінгвістичних експертиз залежить від їхнього типу. Кожна лінгвістична експертиза, зважаючи на перелік питань, які запропоновані для аналізу, підпадає під визначені критерії класифікації, що й зумовлює подальший алгоритм іiі проведення.

Серед конфліктогенних текстів, що є предметом лінгвістичної експертизи, переважають тексти друкованих ЗМІ. Емоційно-експресивна оцінка, яку вони містять, природна: ii не можна повністю вилучити 3 цих текстів. Отже, йдеться про визначення нормативних орієнтирів оцінки. Для лінгвістичної експертизи це питання, що стосуються образи, негативної оцінки, яку містять ті чи ті вислови.

Оцінка в конфліктогенному тексті може бути джерелом експлікації інтенції його автора. Інтенціональність — характерна риса мовного конфлікту, й інтенція автора може бути вилучена виключно з тексту. „Мовленнєвий конфлікт ви- 
никає, коли одна зі сторін на шкоду іншій свідомо активно здійснює мовленнєві дії, які можуть бути виражені у формі докору, зауваження, заперечення, звинувачення, погрози, образи тощо" .

У наукових дослідженнях оцінку пов'язують не тільки з адресантом, що висловлює свої думки, уподобання, смаки, але, можливо, навіть більшою мірою 3 адресатом (Н. Арутюнова, Т. Космеда, А. Романов, А. Ушакова та ін.), діючи на нього в плані вибору того чи того варіанта поведінки, формування переваг тощо. Для лінгвістичної експертизи наявність у тексті оцінок означає можливість експлікації інтенції адресанта.

Ухвалена Пленумом Верховного Суду України постанова № 7 від 28.09.90 „Про застосування судами законодавства, що регулює захист честі, гідності і ділової репутації громадян та організацій” стала важливим чинником у створенні правового механізму розв'язання суперечок та конфліктів, пов'язаних із захистом честі, гідності та ділової репутації громадян та організацій. Названа Постанова регламентує лінгвістичну експертизу як однин із важливих джерел доказів у розв’язку документаційних та інформаційних суперечок і конфліктів.

У п. 6 Постанови роз'яснено, що відповідачем у справі про захист честі й гідності може бути фізична або юридична особа, яка поширила відомості, що порочать позивача. Крім того, у п. 10 та 11 Постанови Пленуму наголошено, що за поширення завідомо неправдивої інформації, що ганьбить потерпілого та принижує його людську гідність непристойними висловлюваннями чи діями, можлива кримінальна (ст.125 і 126, КК) і цивільно-правова відповідальність (ст. 7 та 30 ЦК). Це дає право стверджувати, що в справах, пов'язаних із захистом честі, гідності та ділової репутації, судово-лінгвістична експертиза має на меті визначити об'єктивні лінгвістичні ознаки дифамації в суперечливих текстах.

Публіцистична стаття, що підлягла лінгвістичній експертизі в цій науковій студії, була опублікована на сторінці Інтернет-видання всеукраїнської газети. Лінгвістичний аналіз тексту статті в справі образи честі, гідності та надання інформації негативного характеру щодо особи О. здійснено на підставі клопотання відповідних позивачів.

У процесі здійснення аналізу тексту статті авторка експертизи виходила з постулатів Наказу Міністерства юстиції України № 53/5 від 08 жовтня 1998 р. „Про затвердження Інструкції про призначення та проведення судових експертиз та експертних досліджень” та „Науково-методичних рекомендацій з питань підготовки матеріалів та призначення судових експертиз”, а також документу „Про зміни до цього наказу” (№ 1950/5 від 26.12.2012 р.).

Для здійснення експертизи залучено текст статті журналіста Ж. та два питання для здійснення лінгвістичної експертизи, зокрема це такі питання: 1. Чи має місце негативна інформація у висловлюваннях статті, опублікованої на сторінці Інтернет-видання всеукраїнської газети? 2. Чи можна в контексті поданих фраз виділити такі, що є фактами?

Для відповіді на запропоновані питання в ході відповідної роботи авторка цієї статті спиралася на прецеденти проведення такого типу лінгвістичних екс-

1 T. А. Гридина, В. С. Третьякова, Приничипы лингвокогнитивного анализа конфликтного высказывания 2002, с. 52; См. об этом: Т. В. Чернышова, Юрислингвистическая экспертиза газетно-публицистических текстов с неявной коммуникативной функцией высказывания, [в:] Юрислингвистика 3: Проблемы юрислингвистической экспертизы, Межвуз. сб. науч. трудов, Барнаул 2002. 
пертиз в Україні ${ }^{2}$, зокрема застосовано аксіологічний, компонентний та текстологічний аналізи. Виокремимо основні поняття та терміни, на яких базується експертиза. До них належать такі: 1) висловлювання - найменша одиниця мовлення, що містить відносно закінчений фрагмент інформації, відомостей і лінгвістично оформлена як речення повної чи неповної структури; 2) інформація - повідомлення, відомості про стан справ, конкретні події та факти; інформація про факти та події може бути виражена у формі ствердження чи припущення, інформацію у формі ствердження можна перевірити на відповідність дійсності; 3) негативна інформація - це інформація (відомості), що містять негативну характеристику особи, юридичної чи фізичної, учинків фізичної особи 3 огляду на здоровий глузд, мораль („патологічна ненависть”) чи 3 правового погляду (щодо лінгвістів-експертів - тією мірою, якою це може розуміти кожний дієздатний громадянин, не маючи спеціальних знань у галузі юриспруденції); до негативної інформації лінгвісти-експерти відносять відомості, які містять ствердження про те, що громадянин чи юридична особа порушила чинне законодавство, здійснила нечесний учинок (наголосимо, що висловлювання - це вербальні (словесні) вчинки), неправильно (некоректно) поводилася в особистому, громадському чи політичному житті, під час управлінської, виробничо-господарської чи підприємницької діяльності, порушила ділову етику чи звичаї (норми) ділової комунікації. Уся така інформація принижує честь, достоїнство, гідність чи ділову репутацію громадянина або юридичної особи; 4) думка - це судження, що виражає чиїсь погляди, ставлення до кого-, чого-небудь; думка не може бути істинною чи неправдивою, однак вона може підтвердитися фактами, подіями об'єктивної дійсності; думка може спиратись на факти (цим вона відрізняється від домислу) і містить оцінку фактів і їхній коментар (у цьому ії відмінність від знання); 5) оцінка фактів, подій, осіб: вираження оцінки розпізнаємо в тексті за наявністю конкретних слів і конструкцій з семантикою оцінки, зокрема емоційно-оцінних, емоційно-експресивних, модальних, у значенні яких можна виділити елементи „хороший (позитивний; такий, що відповідає нормі) - поганий (негативний; такий, що не відповідає нормі)"; існують конкретні різновиди оцінки, що характеризують предмет негативно чи позитивно (добрий, злий, порядний, непорядний і т. ін.); за наявності негативної оцінки (виражається формально-семантичними компонентами, що містять семантику „поганий”) ідеться про негативну інформацію; 6) підтекст - це внутрішній прихований зміст відповідного тексту, висловлювання, що може містити позитивну чи негативну інформацію; є) припущеенн, на відміну від ствердження, містить спеціальні маркери - слова, словосполучення, речення, що виражають невпевненість, сумнів, імовірність тієї чи тієї подіï, одну з низки можливих версій (напр.: можливо, імовірно, думаю, уважаю, мабуть і т. ін.); припущення є однією з форм вираження думки, коли автор тексту хоче наголосити, що його докази мають характер попередніх, таких, що потребують уточнення, виражається невпевненість щодо достовірності, обгрунтованості того, про що йдеться: якщо ж підсумкова частина тексту виражена у формі припущення, то таке припущення необхідно розглядати як некатегоричне твердження; 7) співвідношення думки й інформації (відомостей): думка може формуватися на підставі фактів чи бути упередженою, такою, що не базу-

2 T. А. Космеда, Лінгвістична експертиза: практичний аналіз, [в] „MegaLing'2007”, Зб. наук. пр. НАН України, Укр. мовно-інформ. фонд; редкол. Ю. Д. Апресян та ін., Київ 2008, c. $155-164$. 
ється на фактах; людина може формувати свою думку свідомо, раціонально оцінюючи факти, чи не усвідомлюючи, чому вона так уважає, інколи людина керується емоціями і т. ін.; виклад думки (в усній чи писемній формах), на відміну від висловлювання про факти, передбачає вказівку на носія думки; думка містить інформацію не про саму дійсність (факт), а про те, який образ дійсності існує в уявленні мовця; крім того, висловлювання-думка часто репрезентують (переважно приховане) твердження про факти; 8) риторичне питання — це риторична фігура, що містить не відповідь на питання, а твердження; по суті, риторичне питання - це питання, відповідь на яке не потрібна або неочікувана через факт її очевидності; риторичне питання зазвичай використовують для посилення виразності тієї чи тієї фрази; отже, риторичне питання $\epsilon$, по суті, твердженням, що виражене питальною формою, а тому й відповідь на таке питання заздалегідь уже відома ${ }^{3}$; 9) судження - те саме, що міркування, виклад думок, поглядів; 10) твердження - висловлювання, у якому дещо стверджується й відображено зв'язок предмета з його ознаками; граматично твердження (стверджувальне висловлювання) виражається формою розповідного речення неокличного і окличного; твердження можуть бути істинними (відповідають дійсності) чи неістинними (не відповідають дійсності); власне оціночні твердження, як правило, не можна перевірити на відповідність дійсності; 11) фактістинна подія, що справді відбулася, або явище, яке справді існувало чи існує в реальності, дійсне; факти (події) повинні мати матеріали свідчення свого буття і наслідки свого існування, які можна перевірити; для однозначного розуміння значення окремих слів, що використані в статті, подаємо їхнє тлумачення за Словником української мови в 11 томах, що є одним із найавторитетніших словників сучасної української мови.

Спираючись на наведені постулати, експерт надав такі відповіді на поставленні питання, тобто репрезентовано пояснення окремих виразів:

\section{1. „Лексусовий” прокурор (сенсаційні фото).}

„Лексусовий" прокурор - згідно з правописом у лапки беруть: 1) цитати; 2) слова, що їх не вважають за свої або наводять із відтінком презирливого чи іронічного ставлення до чужого вислову; 3) індивідуальні назви літературних творів, наукових праць, газет, журналів, кінофільмів, підприємств, пароплавів тощо 4 . Оскільки „лексусовий” не $\epsilon$ ані цитатою, ані індивідуальною назвою твору, наукової праці, газети, журналу, кінофільму тощо, то з огляду на дискурс статті, яку аналізуємо, зрозуміло: слово "лексусовий" ужито з відтінком презирливого, іронічного ставлення до носія зазначеної ознаки. Прикметник лексусовий — це відносний прикметник, незафіксований у тлумачних словниках української мови: за способом свого утворення виражає ознаку предмета за його відношенням до іншого предмета (у цьому разі до марки автомобіля Lexus - американська гілка японської компанії HYPERLINK 5 ), утворений суфіксальним способом за допомогою додавання до основи іменника суфікса

${ }^{3}$ Див.: 3. Т. Франко, Риторичне запитання, [в:] Українська мова: Енциклопедія, редкол.: В. М. Русанівський, О. О. Тараненко та ін., вид. 2-е, випр. і доп., Київ 2000, с. 551; Д. І. Ганич, І. С. Олійник, Словниклінгвістичних термінів, Київ 1985, с. 228; Словник української мови, в 11 томах, гол. ред. І. К. Білодід, Київ 1987, т. 8, с. 528; Н. А. Колотілова, Риторика, Київ 2007, с. 87.

${ }^{4}$ Український правопис, НАН України, Ін-т мовознавства ім. О. О. Потебні; Ін-т української мови, Київ 2012, с. 180-183.

5 Див.: Електронний ресурс: http://uk.wikipedia.org/wiki/Toyota_Motor_Corporation"/ о’ToyotaMotor Corporation Toyota Motor Corporation (доступ 13.05.2015). 
-ов- та відповідного закінчення. Прикметник лексусовий співзвучний зі словом люксусовий, що має значення "надто розкішний, вигідний, доброякісний”, тобто сенсаційний - той, який викликає або здатний викликати сенсацію; розрахований на сенсацію7 ${ }^{7}$ Проаналізувавши надані лінгвістичні факти, можна зробити висновок, що прикметник ужито з відтінком презирливого, іронічного ставлення до поняття, позначеного іменником прокурор, 3 яким сполучений розглядуваний прикметник: у того, хто читає текст статті, виникають асоціації з чимось „надто розкішним та вигідним”.

Аналізоване висловлювання є розповідним реченням, що має повну структуру (речення номінативне). За способом висловлення це речення стверджувальне. Окрім того, немає жодних метамовних маркерів, що вказували б на наявність сумнівів у автора тексту щодо правдивості викладених фактів. Висловлювання не може бути перевіреним на відповідність дійсності та змодельовано так, щоб навмисне викликати асоціації, які вказують на розкішне життя особи, про яку йдеться в заданому висловлюванні.

2. „Лише деякі витрати, щео їх робить щцотижня прокурор П пан Н, значно перевищують його доходи".

Актуалізувавши значення відповідних слів (деякі - якась частина; поодинокі, не всі ${ }^{8} ;$ значно - дуже, сильно ${ }^{9}$ ), висловлювання кваліфікуємо як розповідне речення з повною структурою, у якому йдеться про факт дійсності без підтвердження його прикладами. Прислівник значно вжито для підсилення семантики дієслова перевищувати. Саме ж речення негативно забарвлене, адже наведена інформація про „витрати, щио ... значно перевищують доходи” стверджує: громадянин порушив чинне законодавство, здійснив нечесний учинок, неправильно (некоректно) поводився в особистому та політичному житті під час своєї діяльності.

3. „Та відкинемо прозу й залишимо голі факти. Отож: п'ятниця, ранок-чорне дороге авто під порогом обласної прокурамури. Тієї самої, де роблять дах із підігрівом та позолотою".

Наведене речення - розповідне висловлювання, у якому вказано, що далі надана інформація є фактом, але наголосимо й на тому, що йдеться про „му саму [прокуратуру], де роблять дах із підігрівом та позолотою”: акцент висловлювання переносено власне на розкіш саме тієї установи (той; займ. не будь-який, не якийсь інший, а саме цей ${ }^{10}$ ). Наявність позолоти в декорі державної установи є неприйнятною та засуджується громадськістю. Отже, саме судження сприяє актуалізації смислу, що виражає негативне ставлення та засудження поведінки, про яку йдеться в тексті статті.

\section{4. „Номер "козирний”, а авто зовсім не міліційне”.}

У цьому висловлюванні вжито прикметник "козирний” (що є козирем ${ }^{11}$; козиряти - розм. 2. перен. Виставляти що-небудь як свою перевагу; хвалитися, чванитися чимось ${ }^{12}$ ): у його прямому значенні немає емоційного забарвлення, він нейтральний за своєю природою, але те, що слова взято в лапки, свідчить про використання виразу в переносному значенні й інформує про належ-

\footnotetext{
${ }^{6}$ Словник украӥнської мови, в 11 томах, гол. ред. І. К. Білодід, Київ 1973, т. 4, с. 572.

7 Там само, 1978 , т. 9, с. 124.

${ }^{8}$ Там само, 1971, т. 2, с. 269.

${ }^{9}$ Там само, 1972 , т. 3 , с. 650 .

${ }^{10}$ Там само, 1979, т. 10, с. 172.

11 Там само, 1973, т. 4, с. 212.

12 Там само.
} 
ність до того, чим можна хвалитися. Отже, висловлювання є твердженням, що сприяє формуванню в читача негативного ставлення до того, що сам по собі номер авто вже є причиною для хвастощів.

5. „Через кілька хвилин працівники прокуратури, як завжди, почнуть завантажувати в багажний відсік цього авто якісь пакети".

Наведене висловлювання $є$ розповідним реченням і містить посилання на факт „завантажсування у багажнний відсік авто пакетів”, хоч у реченні й наявна інформація, репрезентована у формі вставного слова як завжди, що вказує на постійність цієї дії, яку, однак, перевірити важко (як завжди у ролі вставного слова вказує на незмінність дії $\left.{ }^{13}\right)$.

6. „Один із тих, хто бере участь у цьому особливому дійстві, - особисто пан К, начальник відділу матеріально-технічного забезпечення прокурамури".

Наведене висловлювання є розповідним реченням, у якому наголошено на винятковості дії („завантажсування у багажнний відсік авто пакетів”), та на тому, що вона відрізняється від інших схожих дій (порівн.: особливий той, що чимось виділяються серед інших, не такий, як інші, не схожий на інших; незвичайний, винятковий $\left.{ }^{14}\right)$.

\section{7. „Що це за капуста?”}

Надане висловлювання - риторичне питання, тобто таке, що не вимагає відповіді. В аналізованому реченні вжито слово капуста, що в жаргонному мовленні використовують у значенні ,долари США”.

8. „Виадає в очі те, цо на цьому респектабельному авто висить цікавий «синій» номер 1000".

Слово респектабельний використано в значенні „поважний, солідний” 15 ; цікавий - це той, який „привертає увагу, викликає інтерес"16. Актуалізація наведених значень готує читача до сприйняття інформації, що потребує особливої уваги, а відомості, що надаються далі, засвідчують, що власник авто користується перевагами (актуалізовано іронію).

9. „Авто протиправно стоїть прямо на «зебрі» пішоходного переходу, за 20 метрів від знака" стоянка і зупинка заборонені”.

У цьому реченні зебра позначає нерегульований пішохідний перехід ${ }^{17}$. Йдеться про факт порушення правил дорожнього руху.

10. „Табличка «крім авто прокуратури» не дає водію авто жсодної індульгенції, оскільки результати ретельної перевірки засвідчать, щцо в гаражі прокуратури цей автомобіль на обліку не перебуває. Але «Лекcyc» стоїmь".

Зазначене речення є розповідним, що надає інформацію, яку не сприймаємо як припущення: вона містить посилання на факт (відсутність автомобіля на обліку). Крім того, факт підтверджено висловленням про наявність ретельної перевірки. Категоричність висловлювання посилена використанням означального займенника з семантикою повного заперечення - жюдний, що $є$ типовим для речень зі значенням заперечення. Указівка-твердження про факт відсутності прав на вчинену дію (паркування) спонукає до висновку, що це явище не сумісне із посадою зазначеної особи, а тому є негативним (містить нега-

\footnotetext{
${ }^{13}$ А. А. Лучик, Словник еквівалентів слова украӥнської мови, Київ 2008, с. 162.

${ }^{14}$ Словник украӥнської мови, в 11 томах... 1974, т. 5, с. 779.

15 Там само, 1977 , т. 8 , с. 513.

${ }^{16}$ Там само, 1980, т. 11, с. 226.

${ }^{17}$ ПДР України, 1.41.1 Пінохідний перехід (зебра).
} 
тивну інформацію), оскільки автомобіль на обліку в гаражі прокурора не знаходиться. Значення наведених далі слів також посилюють негативний характер наданої інформації (індульгенція - грамота про відпущення гріхів, яку видавала католицька церква від імені папи римського за певні заслуги перед церквою, а також за гроші ${ }^{18}$; ретельний — той, який виявляє старанність, сумлінність у чому-небудь; який здійснюється з урахуванням усіх дрібниць, деталей; грунтовний ${ }^{19}$; алe - cnол., виражає протиставний зв'язок між сурядними реченнями або однорідними членами речення; та, проте, однак ${ }^{20}$ ).

11. „Для прокурорів правила неписані”.

Речення розповідне: це судження містить інформацію, яку автор стверджує, наголошуючи, що вона є очевидною й не потребує доказів. Якщо до назви посади додати, що правила неписані (неписаний - який існує за звичаєм, за традицією; не установлений, не прийнятий офіційно ${ }^{21}$ ), то саме такий вислів стає характерним мовним засобом вираження негативної модальності. „Для прокурорів правила неписані" означає, що люди на таких посадах можуть діяти навіть поза рамками закону і можуть уникнути покарання. 3 огляду на сказане, згаданий вислів приховано (на рівні підтексту) наштовхує на вияв негативного ставлення до запропонованої інформації.

12. „yсі знають, щъо - це висловлювання, що містить посилання на загальновідомий факт, тобто явище про яке, за припущенням автора, мають знати всі.

13. „ «козирний» номер береже його від зайвих контактів із працівниками дорожнньої служсби" (див. пункт 5).

14. „Водій нервує”, „Одним із перших, хто з'явиться звідти, буде прокурор Львівської області пан Баганець власною персоною”.

Висловлювання, що тут наведені, є розповідними реченнями, які містять інформацію про факт дійсності (появу прокурора), крім того, експресивність підсилено словосполученням власною персоною (сам, особисто ${ }^{22}$ ), що в українській мові має несхвальну оцінку та свідчить про негативний характер поданої інформації. Посилена категоричність висловлювання. Негативну інформацію містять і слова нервувати; нервуватися - бути в стані збудження, хвилювання, роздратування ${ }^{23}$.

\section{5. „Ось воно - обличчя нещцдного «борця з корупцісю»”.}

Висловлювання борець з корупцією не містить жодної оцінки в разі вживання його в прямому значенні. Однак використання лапок у тексті засвідчує факт, що словосполучення використано в переносному значенні, іронічно.

16. „До речі, середньомісячна зарплата Президента України 2009 року становила 19614 гривень 25 копійок".

Інформація, що подана після коми, є фактом, адже їі можна перевірити на достовірність, але вираз до речі - аналог прислівника, актуалізований у ролі вставного слова (його використовують у спогадах про таке, що не очікувалось, або було прогаяне ${ }^{24}$ ), міститься перед наданням важливої інформації, що змушує порівнювати іiї з вищезгаданою та наводить на думку про перевищення витрат, які здійснює прокурор, навіть середньомісячної зарплати са-

\footnotetext{
${ }^{18}$ Словник украӥнської мови... 1973, т. 4, с. 28.

19 Там само, 1977 , т. 8, с. 515.

${ }^{20}$ Там само, 1970 , т. 1, c. 33 .

${ }^{21}$ Там само, 1974, т. 5 , с. 354.

22 Словник української мови..., 1975, т. 6, с. 331.

${ }^{23}$ Там само, 1974, т. 5 , с. 375.

${ }^{24}$ А. А. Лучик, Словник еквівалентів слова..., с. 55.
} 
мого президента, що вже, власне, і є негативною інформацією, адже наведені слова дають змогу зробити висновок про зловживання службовим становищем, що, безперечно, є негативною інформацією.

17. „Нехай не платить прокурор і водію «Лексуса", який кожні вихідні ӥзить, як кажуть, за дякую”.

Це висловлення виражає думку, подану у вигляді розповідного речення, що містить маркер припущення нехай, а далі наведено роздуми автора стосовно витрат особи, про яку йдеться (прокурора). Крім того, використані дискурсивні вирази також акцентують увагу читача на наявності негативної інформації (порівн.: як кажуть - у ролі вставного слова, акцентує значення наступного висловлення, ужите в його розмовному варіанті; за дякую - у розмовній українській мові означає 'безкоштовно').

18. „Як не крути, розрахунки показують, щщо офіційних доходів на все таки не вистачає”.

Вираз як не крути (що не роби, як не хитруй, нічого не вдієш ${ }^{25}$ ) і частка таки (ствердж., уживається препозитивно й постпозитивно в значенні сnрав$\left.\partial \boldsymbol{i}^{26}\right)$ також посилюють негативне враження від висловленого. Зазначене речення $є$ розповідним, що відображає інформацію, яку в цьому разі не сприймають як припущення: вона містить твердження, що, разом із фразою як не крути, свідчить про впевненість автора у своїх словах, що підсилено часткою таки.

\section{9. „А якщо не зарплата чи пенсія, то що?"}

$\boldsymbol{A}$ якщцо - розмовна частка, що служить для 3'ясування можливостей відповідної дії, факту ${ }^{27}$. Запитання кваліфікуємо як риторичне, а інформація в риторичному запитанні пов'язана з вираженням додаткових (конотативних) емоційно-експресивних значень. Це судження, на думку автора статті, містить інформацію, що є очевидною і не потребує доказів.

Загальний висновок:

1. У статті „«Лексусовий» прокурор (сенсаційні фото)”, що опублікована на сторінці Інтернет-видання всеукраїнської газети, містяться конкретні висловлювання, де в стверджувальній (часто досить категоричній) формі репрезентована негативна інформація щодо прокурора області пана П.

2. У висловлюваннях, поданих на лінгвістичну експертизу, містяться факти, що потребують доведення, або такі, що нібито мають місце, однак автор висловлювань переконаний, що вони не потребують підтвердження чи є очевидними.

3. Проаналізовані висловлювання репрезентують негативну інформацію, що наштовхує на засудження дій прокурора області. Простежено висловлювання про вчинення незаконних дій, що підтверджує прагнення автора статті переконати читача в тому, що прокурор П. зловживає своїм посадовим становищем, а його витрати перевищують доходи.

Отже, лінгвістична експертиза, здійснена з актуалізацією низки лінгвістичних методів, дала змогу довести, що подані на лінгвістичну експертизу висловлювання є недостовірними, а надана інформація не відповідає дійсності, належить до непрадивих.

\footnotetext{
${ }^{25}$ Словник украӥнської мови... 1973, т. 4, с. 374.

26 Там само, 1979, т. 10, с. 21.

${ }^{27}$ А. А. Лучик, Словник еквівалентів слова..., с. 17.
} 